\title{
Effects of intraperitoneal injection of magnetic graphene oxide on the improvement of acute liver injury induced by $\mathrm{CCl}_{4}$
}

Tahereh Foroutan $^{1 *}$, Fatemeh Ahmadi ${ }^{1}$, Fariborze Moayer ${ }^{2}$ and Sahar Khalvati ${ }^{1}$

\begin{abstract}
Background: Liver failure is usually associated with the inflammation and oxidation of hepatocytes. Due to their unique properties, graphene and graphene-based nanostructures such as magnetic graphene oxide (MGO) are useful in biomedicine and engineering. In this study, synthesized MGO was used to improve the liver failure induced by carbon tetrachloride $\left(\mathrm{CCl}_{4}\right)$. The hepatoprotective effects of intraperitoneal injection of MGO on the rat model of $\mathrm{CCl}_{4}$-induced acute liver failure were investigated.

Materials and methods: In order to provide a rat model of acute liver failure, male rats were intraperitoneally injected with $2 \mathrm{ml} / \mathrm{kg}$ body weight $\mathrm{CCl}_{4}$. In the experimental groups, rats received $2 \mathrm{ml} / \mathrm{kg} \mathrm{CCl}_{4}$ and $300 \mathrm{mg} / \mathrm{kg}$ MGO body weight simultaneously. Four days after injection, symptoms of acute liver failure appeared. The control, sham, $\mathrm{CCl}_{4}$, and $\mathrm{CCl}_{4}+\mathrm{MGO}$ groups were compared and analyzed both histologically and biochemically.

Results: The results indicated that the $\mathrm{MGO}$ injection reduced all $\mathrm{CCl}_{4}$-induced liver failure such as necrosis, fibrosis, inflammation, aspartate transaminase (AST), alanine aminotransferase (ALT), and alkaline phosphatase (ALP) in the experimental groups of the rat model of acute liver failure.

Conclusion: The hepatoprotective effects of MGO might be due to histopathological suppression and inflammation inhibition in the liver.
\end{abstract}

Keywords: Magnetic graphene oxide, Liver, Nanomaterial

\section{Background}

The liver is the main detoxification and metabolic organ in the body. It is therefore vulnerable to different risk factors as well as chronic and acute failures [1]. Hepatic fibrosis is the wound healing response to chronic liver failure caused by viral infections, alcohol abuse, cholestasis, which is characterized by the accumulation of fibrillar extracellular matrix protein, etc. [1-3]. The membrane

\footnotetext{
* Correspondence: foroutan@khu.ac.ir

'Department of Animal Biology, Faculty of Biological Sciences, Kharazmi University, Tehran, Iran

Full list of author information is available at the end of the article
}

components of damaged hepatocytes and infiltrating inflammatory cells can activate Kupffer cells during liver fibrogenesis [4]. Their activation leads to the release of profibrotic factors such as the transforming growth factor, reactive oxygen species, hepatic stellate cells (HSC), and activates important collagen-producing cells in the liver $[5,6]$. HSC activation is characterized by an enhancement in cell growth. In addition, the overproduction of extracellular matrix leads to liver fibrosis [7-9]. Inflammation can greatly stimulate hepatic fibrosis and HSC activation [5].

Liver disorders are associated with mortality risks, and over 100 million people suffer worldwide [3]. Acute 
hepatic failure (fulminant) as a dramatic clinical syndrome is caused by massive hepatic necrosis [10]. The induction of lipid peroxidation by active oxygen species plays a role in the pathogenesis of acute liver failure [9, 11]. Despite spectacular medical advances, there is no specific medication for stimulating liver function to protect it from failure, or regenerate liver cells $[9,12]$.

Today, in addition to regenerative medicine and laser therapy, the use of nano materials has also attracted a lot of attention in medical applications [13, 14]. Due to their unique properties, graphene and graphene-based nanostructures such as magnetic graphene oxide (MGO) are useful materials in biomedicine and engineering [15-17]. Graphene oxide (GO) as a new class of carbon-based materials is a derivative of graphene with a two-dimensional honeycomb structure. The major difference between the graphene and GO is the controllable hydrophilic nature of GO. The hydrophilic nature of GO is because of the existence of several hydroxyl groups on its surface, which makes it resistant to electron transfer. Due to its intrinsic optical properties as well as its small size, ease of use, and large specific surface area [18], GO is recommended for biomedical applications, including biosensors [5], drug/gene delivery $[6,7]$, and antibacterial effects [8]. GO has been reported to possess thermal, electrical, mechanical, and optical properties [19-22]. Biomaterials can be used to promote cell differentiation, attachment, and proliferation. For example, they are used for bone regeneration therapy with stem cells [23].

Growth factors and inducers are crucial for the proliferation and differentiation of stem cells [24-26]. The effectiveness of carbon nanostructures, as well as their modern two- and three-dimensional murid structures have been investigated for regenerative medicine. Graphene and its derivatives have been reported to improve the differentiation potential of stem cells into different lines based on the material types and stem cells [27-29]. These materials have been employed to deliver genes and growth factors into mesenchymal stem cells to manipulate their differentiation [30]. A new approach for the deposition of iron oxide nanoparticles on GO has been proposed, which leads to magnetic GO (MGO) and can be used to improve the biocompatibility of GO and $\mathrm{Fe}_{3} \mathrm{O}_{4}$ through chemical functionalization [29].

In this study $\mathrm{CCl}_{4}$ was used to induce acute liver failure. $\mathrm{CCl}_{4}$ is a well-known hepatotoxin, and is widely used to induce acute and chronic liver failures [9]. A three-dimensional nanoparticle was produced by taking advantage of the innovative capabilities GO and $\mathrm{Fe}_{3} \mathrm{O}_{4}$ nanoparticles in medical and therapeutic applications [29]. Possible in vivo hepatoprotective effects of MGO on the rat model of $\mathrm{CCl}_{4}$-induced acute liver failure were examined.

\section{Methods}

Natural flake graphite powder was supplied by Qingdao Dingding Graphite Products (Shandong, Laixi, China). Other chemicals including $\mathrm{H} 2 \mathrm{SO} 498 \%, \mathrm{H} 2 \mathrm{O} 230 \%, \mathrm{HCl}$ $37 \%$, and $\mathrm{KMnO} 4$ were obtained from Sigma-Aldrich Co. [23].

\section{Preparation of GO nanohybrid}

GO was fabricated using modified Hummer's method, which relied on the oxidation of graphite powder by a strong oxidant medium [31]. Graphite powder $(0.5 \mathrm{~g})$ was placed in a round bottom flask containing $50 \mathrm{~mL}$ of $\mathrm{H}_{2} \mathrm{SO}_{4}$ in an ice bath, and $\mathrm{KMnO}_{4}(2 \mathrm{~g})$ was added gradually. The mixture was stirred for $2 \mathrm{~h}$ below $10^{\circ} \mathrm{C}$ and kept for $1 \mathrm{~h}$ at $35^{\circ} \mathrm{C}$. Subsequently, the reaction medium was diluted with $50 \mathrm{~mL}$ distilled water in the ice bath, while the temperature was kept below $100^{\circ} \mathrm{C}$, and left to stir for $1 \mathrm{~h}$. It further diluted to nearly $150 \mathrm{~mL}$ with distilled water. In order to eliminate excess permanganate ion, $10 \mathrm{~mL}$ of $\mathrm{H}_{2} \mathrm{O}_{2} 30 \%$ was added afterwards which turned the color of the reaction mixture into brilliant yellow. The final product was centrifuged and washed with $5 \% \mathrm{HCl}$ followed by distilled water several times and the resulting solid was dried at $60^{\circ} \mathrm{C}$ for $24 \mathrm{~h}$. The preparation of $\mathrm{MGO}$ was based on the protocol by Kassaee et al. [32] and Foroutan et al. [33].

\section{Characterization}

The prepared GO nanosheets were characterized using X-ray diffraction (XRD, Philips Xpert MPD Co. 1.78897 $\AA$ A), scanning electron microscopy (SEM, Philips XL30 microscope, $25 \mathrm{kV}$ accelerating voltage), transmission electron microscopy (TEM, Philips, EM208S, Netherlands, 100 $\mathrm{kV}$ acceleration voltage), atomic force microscopy (AFM, VEECO, CP-Research), and micro Raman spectroscopy (Almega Thermo Nicolet Dispersive Raman Spectrometer, excitation wavelength of $532 \mathrm{~nm}$ ). MGO preparation was performed according to the previous study [32].

\section{Animals}

The rats were kept in an animal room in a controlled temperature of $23 \pm 2{ }^{\circ} \mathrm{C}$ and equal 12-h light/dark cycles with free access to food and water. All procedures were carried out in accordance with the Iranian code of conduct for the care and use of experimental animals for scientific purposes. The rat model of acute liver failure was prepared using a single intraperitoneal injection of $\mathrm{CCl}_{4}(2 \mathrm{ml} / \mathrm{kg}$ body weight) dissolved in sterile olive oil (1:1). After 4 days of injection, symptoms of acute liver failure such as biochemical and histological analysis were observed.

To investigate the effects of MGO on acute liver failure in the rat models, male rats were randomly divided into four groups: in the first group (control) rats were intraperitoneally injected with olive oil, in the second 

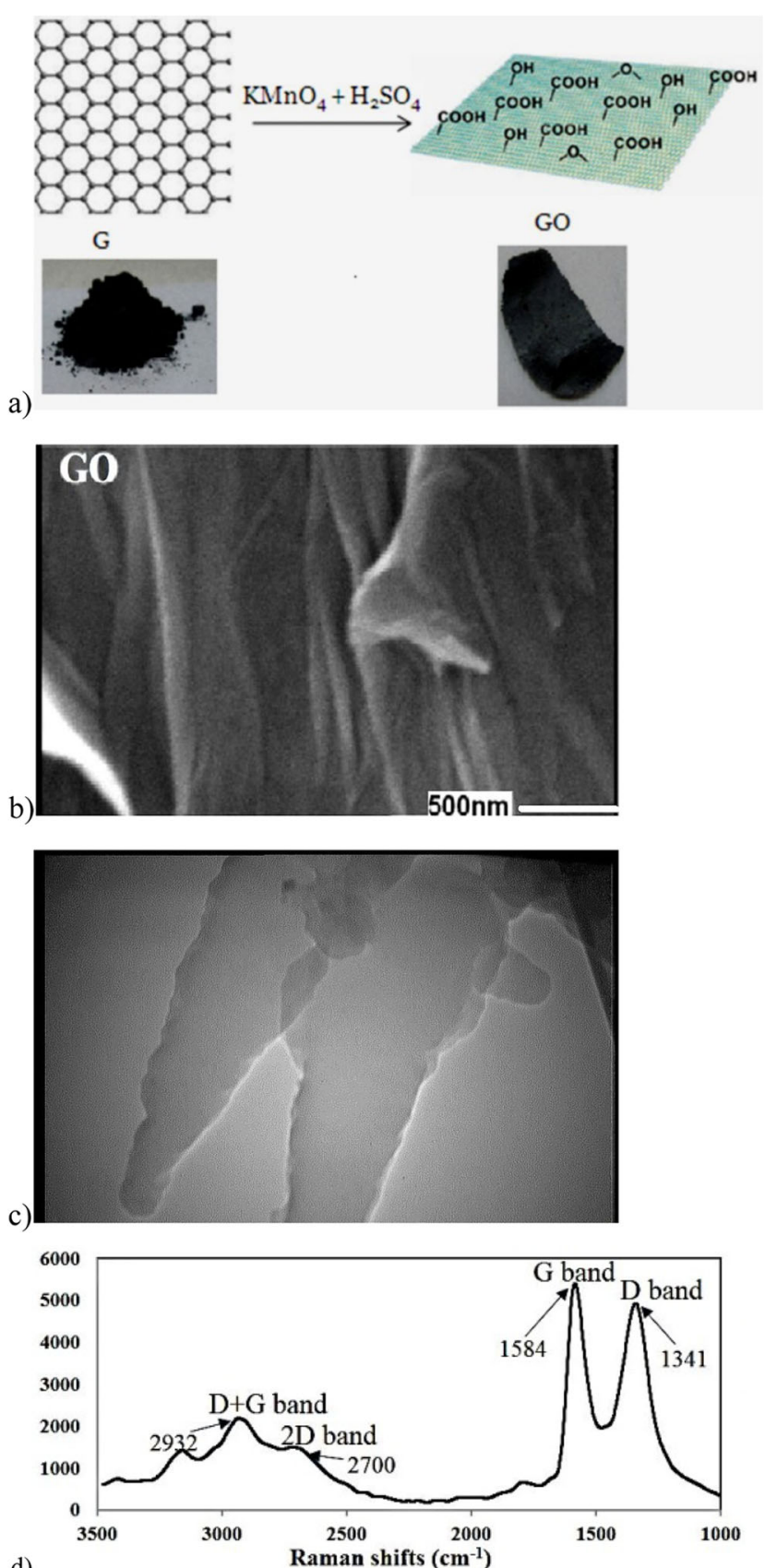

d)

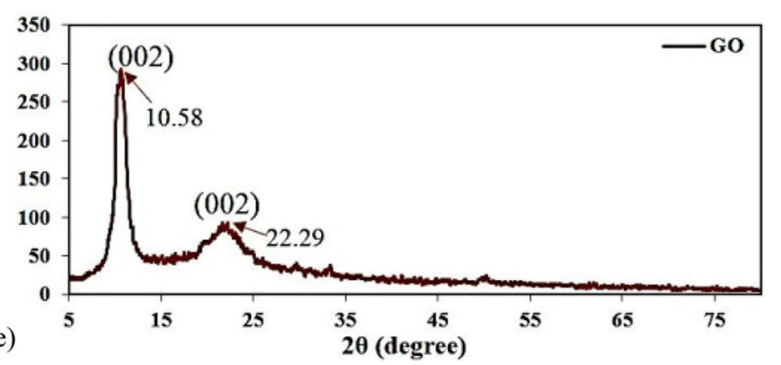

Fig. 1 Synthessis of GO nanostructures from graphite (a); scaning electron microscopy (b); transmitision electon microscopy image of synthesized $\mathrm{GO}$ nanosheets (c); raman spectrum (d); XRD pattern of GO nanosheets (e) 
group (sham) they received $2 \mathrm{ml} / \mathrm{kg}$ body weight olive oil, in the third group $\left(\mathrm{CCl}_{4}\right)$ they were injected with 2 $\mathrm{ml} / \mathrm{kg}$ body weight $\mathrm{CCl}_{4}$, and in the fourth groups, they were injected with $\mathrm{CCl}_{4}$ and $300 \mathrm{mg} / \mathrm{kg}$ body weight MGO. The animals were anesthetized $24 \mathrm{~h}$ after the last injection using the mixture of ketamine $10 \%$ and xylazine 2\% (both from Alfasan, Netherland). Blood samples from the heart were collected and the liver was then removed for histological examination.

\section{Histological tests}

Liver tissues were fixed with formalin and embedded then in paraffin. Thin sections were stained with H\&E, caspase-3 and IL-6. Hyperemia, apoptosis, and inflammatory cells were assessed according to no effect (-), mild effect $(++)$, and intensive effect $(+++)$. The Immunohistochemical (IHC) staining of caspase-3 and IL-6 was used to investigate the apoptosis and inflammation respectively. The number of apoptotic and inflammatory cells was also counted.

\section{Serum biochemical analysis}

Blood samples were kept at room temperature for $1 \mathrm{~h}$, and centrifuged then at $1500 \mathrm{~g}$ for $10 \mathrm{~min}$ at $4{ }^{\circ} \mathrm{C}$. The serum was separated and kept in $20^{\circ} \mathrm{C}$ before analysis. The activity of AST, ALT, and ALP was measured using an automated analyzer (Hitachi, Japan) and available kits (Pars Azmoon, Iran) according to the manufacturer's instructions.

\section{Results}

Figure 1 shows the schematic representation of synthesis of the GO nano-hybrid and also its characterization. AST, ALT, and ALP are the pathological indices for hepatic death and failure [1]. As compared to the $\mathrm{CCl}_{4}$ group, the ALT/AST/ALP levels were significantly reduced in the $\mathrm{CCl}_{4}+\mathrm{MGO}$ group $(p<0.001)$ (Fig. 2). $\mathrm{CCl}_{4}$ administration caused hepatic failure, including hepatocyte apoptosis, inflammation, and hyperemia (Table 1). The protective effects of MGO were assessed through biochemical and histological examination of the samples. The number of inflammatory cells (neutrophils, lymphocytes, and Kupffer cells) was counted using a 400x magnification optical microscope in 10 visual fields in the H\&E slides of each sample (Figs. 3, 4 and Table 1). The results of $\mathrm{H} \& \mathrm{E}$ staining showed that the $\mathrm{CCl}_{4}$ injection led to a significant apoptosis and inflammation of liver cells, while MGO significantly reduced the area of apoptosis as well as the inflammatory cells. Moreover, a significant increase in the inflammatory cells in the $\mathrm{CCl}_{4}$ group compared to the control group was observed. The results also suggested the effectiveness of MGO treatment in reducing inflammatory and apoptotic cells $(p<0.001)$. The number of dead cells and the incidence of hyperemia in the experimental groups were lower than those in the control group. Intraperitoneal injection of $\mathrm{CCl}_{4}$ induced apoptosis and inflammation in the liver cells. Our results showed that the administration of MGO significantly reduced the apoptotic and inflammatory liver cells induced by $\mathrm{CCl}_{4}$.

The results of IHC staining showed that MGO plays an anti-apoptotic and anti- inflammation roles in the repair of damaged tissue. Positive nuclear staining for caspase3 and IL- 6 markers occurredin greater than 20 and $25 \%$ of the liver cells of failure models respectively, which indicated a high apoptosis and inflammation index, compare to the MGO treatment (10\%) and control (8\%) groups respectively (Figs. 5, 6 and 7).
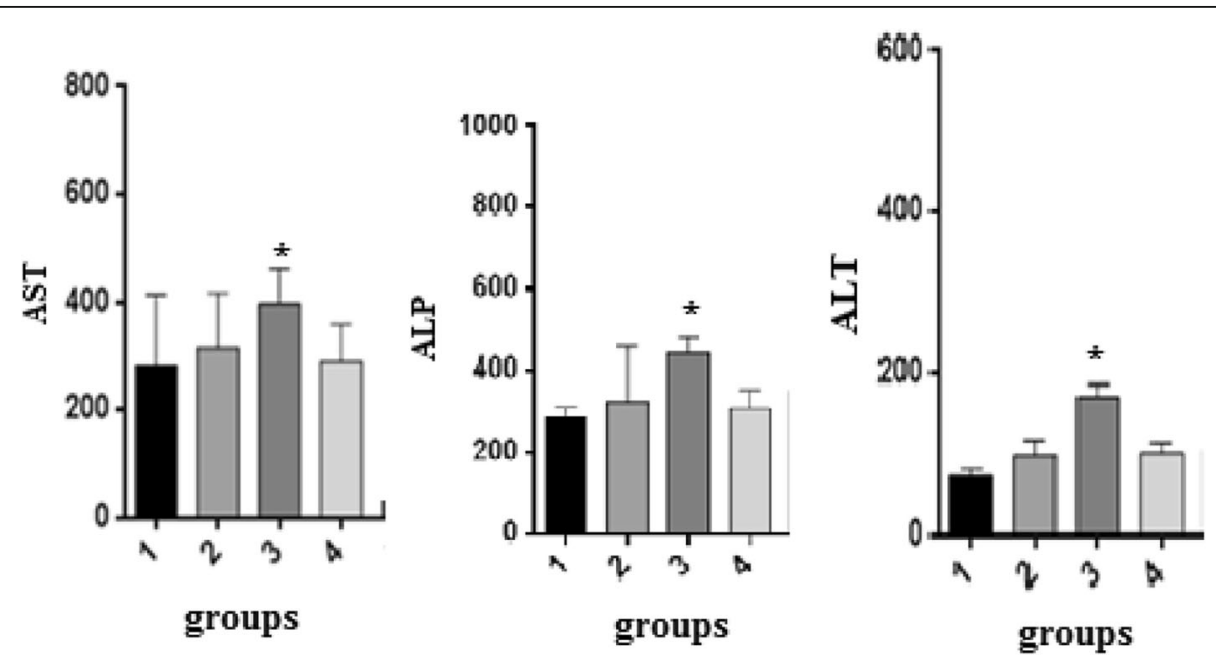

Fig. 2 Effects of magnetic $\mathrm{GO}$ treatment on serum biochemical parameters in rat models of $\mathrm{CCl}_{4}$-induced acute liver failure. Magnetic $\mathrm{GO}$ treatment reduced serum $\operatorname{ALT}(\mathbf{a}), \operatorname{AST}(\mathbf{b})$, and $\operatorname{ALP}(\mathbf{c})$ in rats' liver induced by $\mathrm{CCl}_{4}(n=6)$. ALT: alanine aminotransferase, AST: aspartate, aminotransferase, ALP: alkaline phosphatase. $P<0.05$. Control (1); sham (2); $\mathrm{CCl}_{4}$ (3); received $300 \mu \mathrm{g} / \mathrm{kg}$ weight body (4) 
Table 1 Microscopic evaluation of hepatocytes in different treatments groups

\begin{tabular}{lllll}
\hline Sample & Hyperemia & Accumulation of inflammatory cells & \% apoptosis & Average apoptotic cells per field \\
\hline 1 & - & - & 0 & - \\
2 & - & - & 0 & - \\
3 & +++ & +++ & 17.71 & 52 \\
4 & ++ & ++ & 11.14 & 29 \\
\hline
\end{tabular}

1: Control group; 2: Sham group (olive oil); $3: \mathrm{CCl}_{4}+$ olive oil; 4: $\mathrm{CCl}_{4}+$ olive oil + magnetic GO. no effect (-), mild effect (++), intensive effects (+++). Evaluation of the infiltration of inflammatory cell and hyperemia: slight $(+)$; mild $(++)$; intense $(+++)$

\section{Discussion}

It has been shown that $\mathrm{CCl}_{4}$-induced hepatotoxicity can lead to acute liver failure with fibrosis, cirrhosis [9, 34], and hepatocellular necrosis [35]. Cytochrome P450 metabolizes $\mathrm{CCl}_{4}$ into free radicals trichloromethyl $\left(\mathrm{CCl}_{3}\right)$ or trichloroperoxyl $\left(\mathrm{CCl}_{3} \mathrm{O}_{3}\right)$ in the liver [36]. These free radicals cause lipid peroxidation which leads to hepatocytes necrosis, and induces inflammation. It further promotes the progress of hepatic fibrogenesis (Perez Tamayo, [37]), which in turn results in lipid peroxidation, hepatocytes necrosis and inflammation. Oxidative stress is closely associated with fibrosis and hepatic necrosis [38]. There is also a connection between the serum enzymes activities with liver parenchymal failure and the increased level of these enzymes can be used as a marker for the detection of acute liver damage [39]. The free radicals induced by $\mathrm{CCl}_{4}$ attack hepatocytes and cause parenchymal cell death. This in turn leads to inflammatory reactions in the liver [20]. The infiltration of inflammatory cells plays an important role in the progress of thymus damages.

Since deposition of iron oxide nanoparticles on GO has been suggested for improving the chemical functionalization of GO, in the present study we used the magnetic form of GO to treat liver failure [29]. The applicability of magnetic nanoparticles (tissue repair, drug delivery, biosensor technology) with tailored surface properties and appropriate physicochemistry has been investigated $[40,41]$. The strong magnetic properties of $\mathrm{Fe}_{3} \mathrm{O}_{4}$ have gained particular attention for medical and biotechnological purposes [42-44]. The combination of $\mathrm{GO}$ with various polymers has applications in drug delivery [45]. Such limitations might cause inappropriate drug loading and rapid drug elution [46].

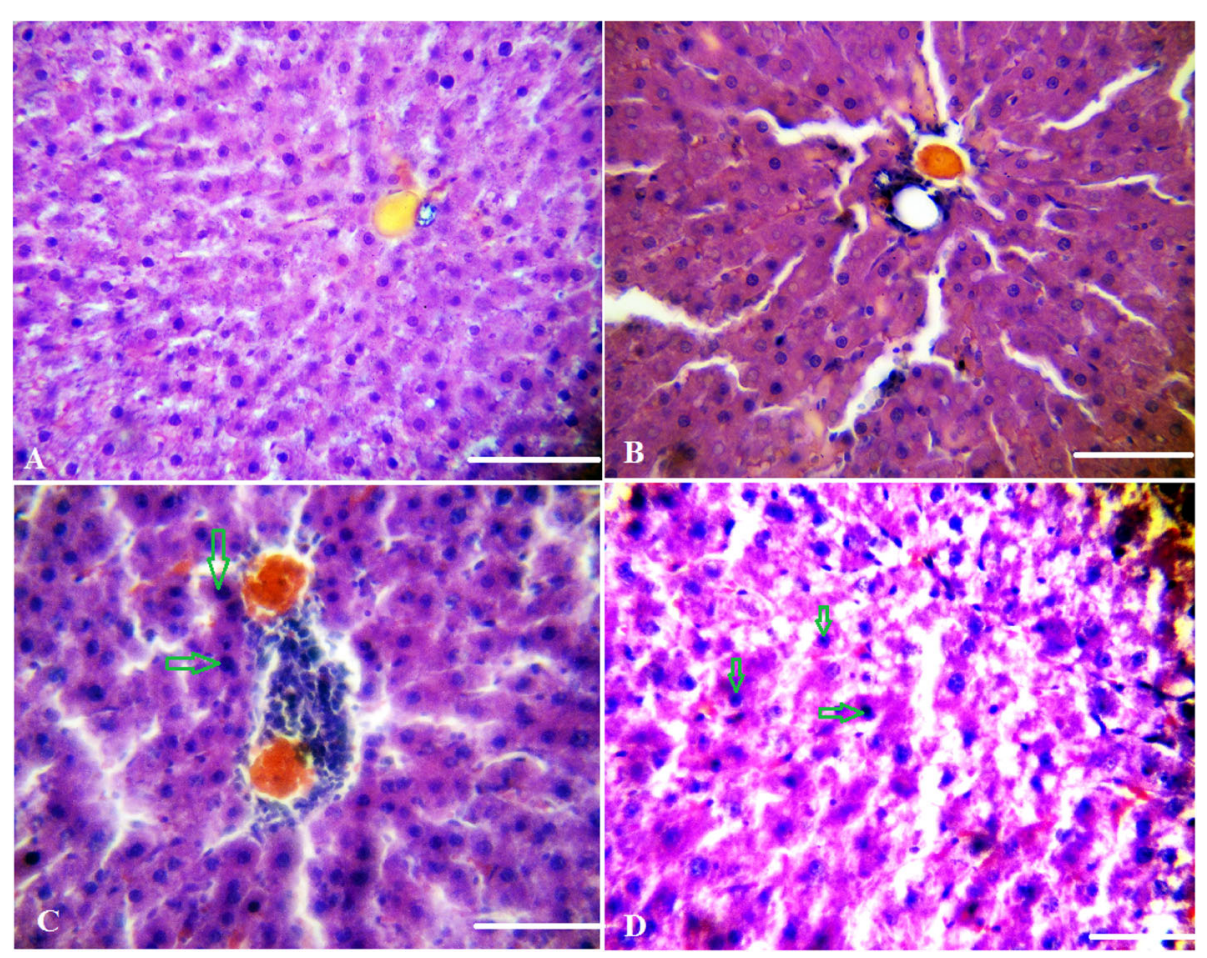

Fig. 3 Photomicrograph of liver tissue in control (a), sham (b), and $\mathrm{CCl}_{4}$-induced liver failure (d, c) groups. $\mathbf{a}$ and $\mathbf{b}$ indicate normal liver cells. Arrows indicate apoptotic cells. H \&E staining. Magnification: 400x. Scale bar $=100 \mu \mathrm{m}$ 


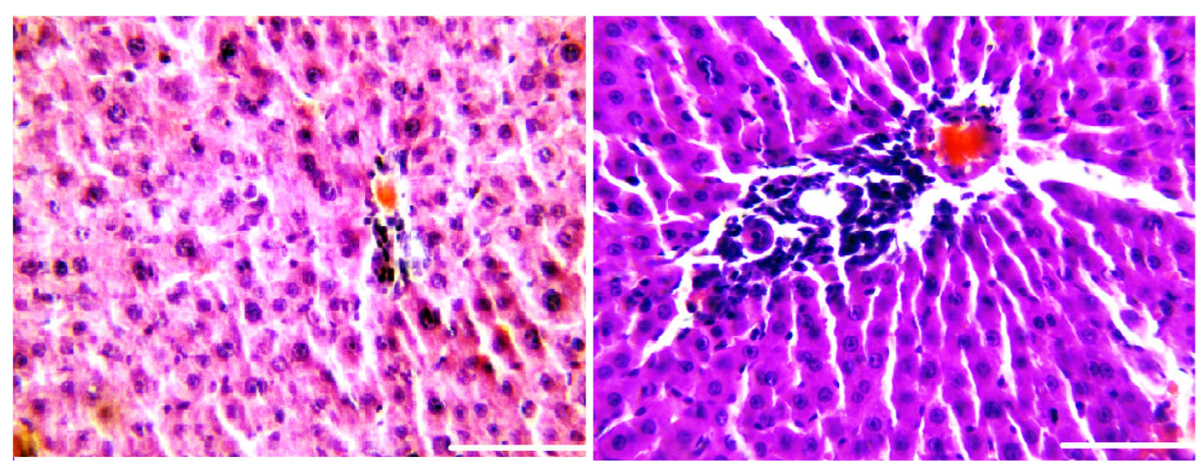

Fig. 4 Effects of magnetic $\mathrm{GO}$ on the improvement of rat models of $\mathrm{CCl}_{4}$-induced acute liver failure. The reduction of dead cells and hyperemia in the experimental groups compared to the untreated group (Fig. 3c and d) is visible. Magnification: 400x. Scale bar $=100 \mu \mathrm{m}$

However, polymeric hydrogels suffer from limitations such as toxicity, unstable physiological conditions, inhomogeneous structure, and the presence of crosslinking agents [47].

In our study, we observed a significant reduction in AST and ALT serum levels (which are pathological indices for hepatic death and hepatic failure) in the $\mathrm{CCl}_{4}+$ MGO group compared to the $\mathrm{CCl}_{4}$ group $(p<0.001)$. Our previous study demonstrated the effectiveness of intraperitoneal injection of GO in improving the cisplatininduced acute kidney failure [32]. On the other hand, the chemical functionalization of $\mathrm{GO}$ and $\mathrm{Fe}_{3} \mathrm{O}_{4}$ can be used to improve its biocompatibility [29]. Because of its low toxicity and strong magnetic properties, $\mathrm{Fe}_{3} \mathrm{O}_{4}$ has attracted great attention in medicine and biotechnology [29].

It has been reported that in the presence of $\mathrm{GO}$, serum proteins and growth factors are more efficiently adsorbed on the surface of cells [46, 48]. The more $\mathrm{Fe}_{3} \mathrm{O}_{4} @ \mathrm{GO}$ is adsorbed; it provides more essential biomolecules for the cell growth. A cell secretes various compounds for its growth and communication with surrounding cells. These substances are adsorbed on the surface of $\mathrm{GO} @ \mathrm{Fe}_{3} \mathrm{O}_{4}$ through ionic bonding and hydrophobic interactions, and affect cell proliferation and differentiation. Inflammatory cells can generate a broad range of cytokines, in particular $\mathrm{IL}_{6}$ and TNF- $\alpha$ [49]. High levels of $\mathrm{IL}_{6}$ can cause hepatic HSC activation and

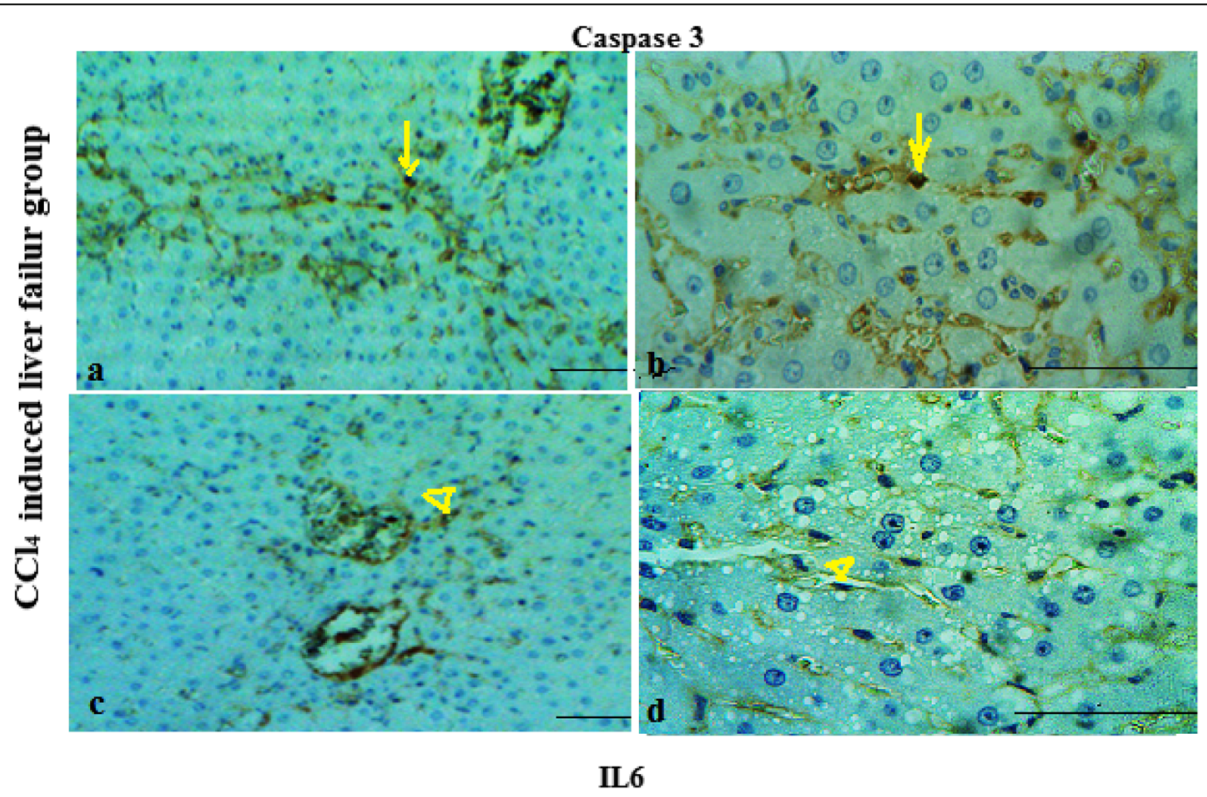

Fig. 5 Micrographs of the $\mathrm{CCl}_{4}$-induced liver failure stained with caspase-3 $(a, b)$ and $\mathrm{IL}-6(\mathrm{c}, \mathrm{d})$ antibodies. Arrows and head arrows indicate apoptosis and inflammatory cells respectively. Numerous positive caspase-3 and IL-6 are visible. Magnification: 100x (a, c) and 400x (b, d). Scale bar $=100 \mu \mathrm{m}$ 


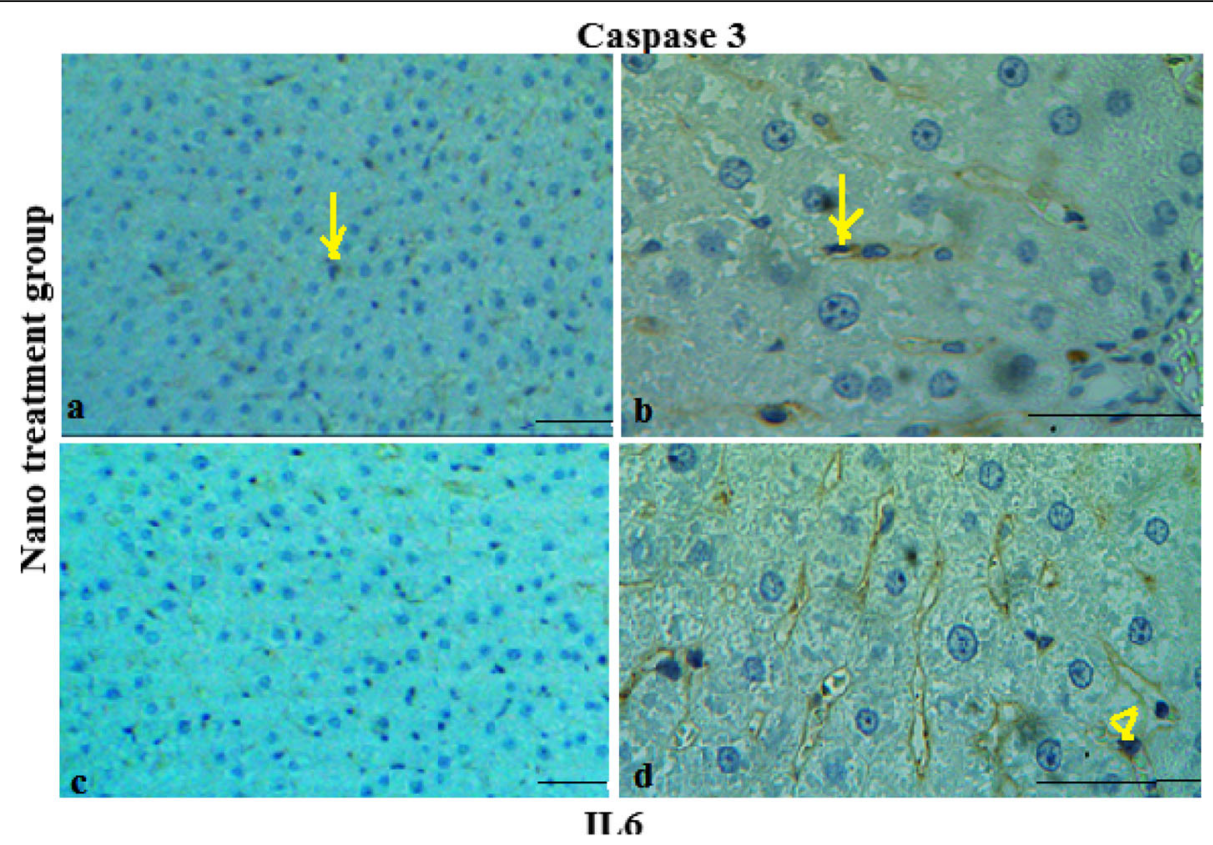

Fig. 6 Micrographs of the $\mathrm{CCl}_{4}$-induced liver failure treated with nano-injection stained with caspase-3 (a, b) and IL-6 (c, d) antibodies. Arrows and head arrows indicate apoptosis and inflammatory cells respectively. Magnification: 100× (a, c) and 400× (b, d). Scale bar $=100 \mu \mathrm{m}$

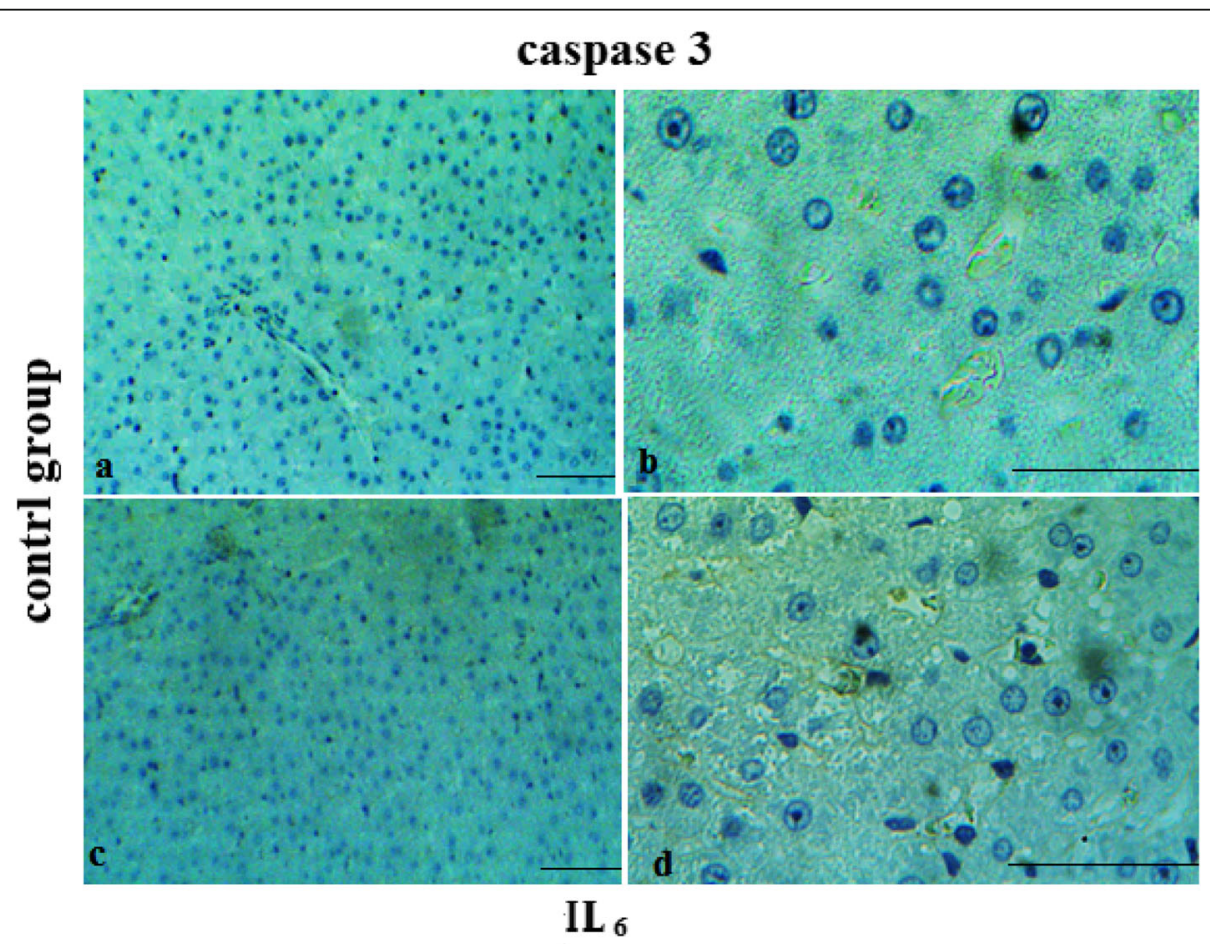

Fig. 7 Micrographs of the liver in control group (received no treatment) stained with caspase-3 $(\mathbf{a}, \mathbf{b})$ and $\mathrm{IL}_{6}(\mathbf{c}$, $\mathbf{d})$ antibodies. Magnification: $100 \times(\mathbf{a}, \mathbf{c})$ and $400 \times(\mathbf{b}, \mathbf{d})$ 
extra cellular matrix production, which promotes fibrosis in the liver. This study demonstrated that MGO significantly reduced infiltrating inflammatory cells in the liver after the $\mathrm{CCl}_{4}$ treatment. Due to the suitability of the product with its high cytocompatibility in biomedicine, for example as a drug carrier [39], we concluded that MGO accelerates the improvement of acute liver failure. The results for IHC staining showed that the MGO injection led to a significant reduction in the apoptotic $(29 \pm 0.2)$ and inflammatory cells $(23 \pm 0.3)$ in the $\mathrm{CCl}_{4}$-induced liver $(P<0.05)$ compared to liver induced by $\mathrm{CCl}_{4}$ group $(52 \pm 0.2)$ and $(41 \pm 0.3)$ respectively. Apoptosis is associated with various pathological situations, and occurs in response to a variety of cytotoxic stimuli. It plays a key role in developmental biology. Various mediators are secreted from immune system cells during the inflammation, such as $\mathrm{IL}_{6}$, which intensify the immune response [49]. $\mathrm{IL}_{6}$ has antiinflammatory effects and leads to the releases of liver proteins in the acute stage. Indeed, inflammation and its symptoms are the result of a rapid increase in the secretion of inflammatory mediators such as IL- 1 and $\mathrm{IL}_{6}[50$, 51]. IHC staining confirmed that the use of MGO could reduce the number of apoptotic and inflammatory cells caused by liver failure.

\section{Conclusion}

This study indicated that treatment with MGO helped improve $\mathrm{CCl}_{4}$-induced acute liver failure. MGO surface improved adsorption of secreted growth factors within the blood. It enabled hepatocytes to better reach and interact with damaged and healthy cells. Moreover, MGO enhanced cells' interactions with each other as well as with extra cellular matrix. It appeared therefore that MGO could be used in combination with hepatocytes to treat diseases in vivo. We concluded that MGO reduces apoptosis and inflammation of liver cells and accelerates the absorption and loading of growth factors and therefore improved the protective effects of cells.

\section{Abbreviations}

MGO: Magnetic graphene oxide; $\mathrm{CCl}_{4}$ : Carbon tetrachloride; AST: Aspartate transaminase; ALT: Alanine aminotransferase; ALP: Alkaline phosphatase; HSC: Hepatic stellate cells; GO: Graphene oxide; IHC: Immunohistochemical; IL6: Interleukin 6; H\&E: Hematoxiline and eosin

\section{Acknowledgments}

Not applicable.

\section{Authors' contributions}

FT contributes to data handling, study design, supervision, and draft preparation. FA and FM contributed to experimental analysis. SK contributes to data analysis. The author(s) read and approved the final manuscript.

\section{Availability of data and materials}

All data generated and analyzed during the current study are available from the corresponding author on reasonable request.

Ethics approval and consent to participate

Not applicable.

Consent for publication

Not applicable.

\section{Competing interests}

The authors declare that they have no competing interests.

\section{Author details}

'Department of Animal Biology, Faculty of Biological Sciences, Kharazmi University, Tehran, Iran. ${ }^{2}$ Department of Pathobiology, School of Veterinary Medicine, Karaj Branch, Islamic Azad University, Karaj, Iran.

Received: 13 February 2020 Accepted: 22 July 2020

Published online: 26 August 2020

\section{References}

1. Fu Y, Zheng S, Lin J, Ryerse J, Chen A. Curcumin protects the rat liverfrom $\mathrm{CCl}_{4}$-caused injury and fibrogenesis by attenuating oxidative stress and suppressing inflammation. Mol Pharmacol. 2008;73:399-409.

2. Benyon RC, Arthur MJ. Extracellular matrix degradation and the role of hepatic stellate cells. Semin Liver Dis. 2001;21:373-84.

3. Manuelpillai U, Tchongue J, Lourensz D, Vaghjiani V, Samuel CS, Liu A, et al. Transplantation of human amnion epithelial cells reduces hepatic fibrosis in immunocompetent $\mathrm{CCl}_{4}$-treated mice. Cell Transplant. 2010;19:1157-68.

4. Hayashi S, Itoh A, Isoda K, Kondoh M, Kawase M, Yagi K. Fucoidan partly prevents $\mathrm{CCl}_{4}$-induced liver fibrosis. Eur J Pharmacol. 2008;580:380-4.

5. Greenwel P, Dominguez-Rosales JA, Mavi G, Rivas-Estilla AM, Rojkind M. Hydrogen peroxide: a link between acetaldehyde-elicited alpha1 (I) collagen gene up-regulation and oxidative stress in mouse hepatic stellate cells. Hepatology. 2000;31:109-16.

6. Lee KS, Buck M, Houglum K, Chojkier M. Activation of hepatic stellate cells by TGF alpha and collagen type I is mediated by oxidative stress through cmyb expression. J Clin InvesJ Clin Invest. 1995;96:2461-8.

7. Arthur MJ, Mann DA, Iredale JP. Tissue inhibitors of metalloproteinases, hepatic stellate cells and liver fibrosis. J Gastroenterol Hepatol. 1998;13 Suppl:33-8.

8. Benyon RC, Arthur MJ. Mechanisms of hepatic fibrosis. J Pediatr Gastroenterol Nutr. 1998;27:75-85.

9. Ghasemi M, Azarnia M, Jamali M, Mirabolghasemi G, Nazarian S, Naghizadeh $\mathrm{MM}$, et al. Protective effects of Ephedra pachyclada extract on mouse models of carbon tetrachloride- induced chronic and acute liver failure. Tissue Cell. 2014:46:78-85.

10. Newsome PN, Plevris JN, Nelson $\sqcup$, Hayes PC. Animal models of fulminant hepatic failure: a critical evaluation. Liver Transpl. 2000;6:21-31.

11. Arthur MJ. Reactive oxygen intermediates and liver injury. J Hepatol. 1988;6: $125-31$.

12. Chattopadhyay RR. Possible mechanism of hepatoprotective activity of Azadirachta indica leaf extract: part II. J Ethnopharmacol. 2003;89:217-9.

13. Paganelli A, Tarentini E, Benassi L, Kaleci S, Magnoni C. Mesenchymal stem cells for the treatment of psoriasis: a comprehensive review. Clin Exp Dermatol. 2020. https://doi.org/10.1111/ced.14269.

14. Ayobian-Markazi N, Fourootan T, Zahmatkesh A. An in vitro evaluation of the responses of human osteoblast-like SaOs-2 cells to SLA titanium surfaces irradiated by erbium: yttrium-aluminum-garnet (Er: YAG) lasers. Lasers Med Sci. 2014;29(1):47-53.

15. Rao CNR, Sood AK, Subrahmanyam KS, Govindaraj A. Graphene: the new two-dimensional nanomaterial. Angew Chem Int Ed. 2009;48:7752-77.

16. Geim AK. Graphene: status and prospects. Science. 2009;324:1530-4.

17. Zhu Y, Murali S, Cai W, Li X, Suk JW, Potts JR, et al. Graphene and graphene oxide: synthesis, properties, and applications. Adv Mater. 2010;22:3906-24.

18. Goncalves G, Vila M, Portoles M-T, Vallet-Regi M, Gracio J, Marques PA. Nano-graphene oxide: a potential multifunctional platform for cancer therapy. Adv Healthc Mater. 2013;2:1072-90. 
19. Balandin AA, Ghosh S, Bao WZ, Calizo I, Ghosh S, Bao WZ, Calizo I, Teweldebrhan D, Miao F, Lau CN. Superior thermal conductivity of singlelayer graphene. Nano Lett. 2008;8:902-7.

20. Gomez-Navarro C, Weitz RT, Bittner AM, Scolari M, Mews A, Burghard M, et al. Electronic transport properties of individual chemically reduced graphene oxide sheets. Nano Lett. 2007;7:3499-503.

21. Lee C, Wei XD, Kysar JW, Hone J. Measurement of the elastic properties and intrinsic strength of monolayer graphene. Science. 2008;321:385-8.

22. Stoller MD, Park SJ, Zhu YW, An JH, Ruoff RS. Graphene- based ultracapacitors. Nano Lett. 2008;8:3498-502.

23. Foroutan T, Nazemi N, Tavana M, Kassaee MZ, Motamedi E, Soieshargh $S$, et al. Suspended graphene oxide nanoparticle for accelerated multilayer osteoblast attachment. J Biomed Mater Res Part A. 2018;106: 293-303.

24. Abedi A, Azarnia M, Jamali Zhvarehy M, Foroutan T, Golestani S. Effect of different times of Intraperitoneal injections of human bone marrow mesenchymal sStem cell conditioned medium on gentamicin-induced acute kidney injury. Urology J. 2016;13(3):2707-16.

25. Foroutan T, Farhadi A, Abrun S, Soltani MB. Adipose derived stem cells affect mir-145 and P53 expression of co-cultured hematopoietic stem cells. Cell J. 2018;19(4):654-9.

26. Eini F, Foroutan T, Bidadkosh A, Barin A, Dehghan MM, Tajik P. The effects of freeze/thawing process on cryopreserved equine umbilical cord bloodderived mesenchymal stem cells. Comp Clin Pathol. 2012;21(6):1713-8.

27. Nayak TR, Andersen H, Makam VS, Khaw C, Bae S, Xu XF, Ee PLR, Ahn JH, Hong BH, Hong BH, Pastorin G, Ozyilmaz B. Graphene for controlled and accelerated osteogenic differentiation of human mesenchymal stem cells. ACS Nano. 2011:5:4670-8.

28. Lee WC, Lim CHYX, Shi H, Tang LAL, Wang Y, Lim CT, Loh KP. Origin of enhanced stem cell growth and differentiation on graphene and graphene oxide. ACS Nano. 2011;5:7334-41.

29. Urbas K, Aleksandrzak M, Jedrzejczak M, Rakoczy R, Chen X, Mijowska E. Chemical and magnetic functionalization of graphene oxide as a route to enhance its biocompatibility. Nanoscale Res Lett. 2014;9:656.

30. Talukdar Y, Rashkow JT, Lalwani G, Kanakia S, Sitharaman B. The effects of graphene nanostructures on mesenchymal stem cells. Biomaterials. 2014;35: 4863-77.

31. Hummers WS, Offeman RE. Preparation of graphitic oxide. J Am Chem Soc. 1958;80(6):1339.

32. Kassaee $\mathrm{MZ}$, Motamedi $\mathrm{E}_{1}$ Majdi $\mathrm{M}$. Magnetic $\mathrm{Fe}_{3} \mathrm{O}_{4}$-graphene oxide/ polystyrene: Fabrication and characterization of a promising nano composite. Chem Engin J. 2011;172:540-9.

33. Foroutan T, Nafar M, Motamedi E. Intraperitoneal injection of graphene oxide nanoparticle accelerates stem cell therapy effects on acute kidney injury. Stem Cells Cloning. 2020;13:21.

34. Weber LW, Boll M, Stampfl A. Hepatotoxicity and mechanism of action of haloalkanes: carbon tetrachloride as a toxicological model. Crit Rev Toxicol. 2003;33:105-36.

35. Rao PS, Mangipudy RS, Mehendale HM. Tissue injury and repair as paralle and opposing responses to $\mathrm{CCl}_{4}$ hepatotoxicity: a novel dose-response. Toxicol. 1997:118:181-93.

36. Burk RF, Lane JM, Patel K. Relationship of oxygen and glutathione in protection against carbon tetrachloride-induced hepatic microsomal lipid peroxidation and covalent binding in the rat. Rationale for the use of hyperbaric oxygen to treat carbon tetrachloride ingestion. J Clin Invest. 1984;74:1996-2001.

37. Perez TR. Is cirrhosis of the liver experimentally produced by $\mathrm{CCl}_{4}$ and adequate model of human cirrhosis? Hepatology. 1983;3:112-20.

38. Poli G, Parola M. Oxidative damage and fibrogenesis. Free Radic Biol Med. 1997;22:287-305.

39. Gressner OA, Weiskirchen R, Gressner AM. Biomarkers of liver fibrosis: clinical translation of molecular pathogenesis or based on liver-dependent malfunction tests. Clin Chim. 2007;381:107-13.

40. Yu MK, Jeong YY, Park J, Park S, Kim JW, Min JJ, Kim K, Jon S. Drug-loaded superparamagnetic iron oxide nanoparticles for combined cancer imaging and therapy in vivo. Angew Chem Int Ed Engl. 2008:47:5362-5.

41. Huh YM, Jun YW, Song HT, Kim S, Choi J-S, Lee J-H, et al. In vivo magnetic resonance detection of cancer by using multifunctional magnetic nanocrystals. J Am Chem Soc. 2005;127:12387-91.

42. Moroz P, Jones SK, Gray BN. Magnetically mediated hyperthermia: currentstatus and future directions. Int J Hyperth. 2002;18:267-84.
43. Jordan A, Wust P, Fahling H, John W, Hinz A, Felix R. Inductive heating of ferromagnetic particles and magnetic fluids: physical evaluation of their potential for hyperthermia. Int J Hyperthermia. 1993;9:51-68.

44. Gupta AK, Gupta M. Synthesis and surface engineering of iron oxide nanoparticles for biomedical applications. Biomater. 2005;26:3995-4021.

45. Kumeria T, Bariana M, Altalhi T, Kurkuri M, Gibson CT, Yangd W, et al. Graphene oxide decorated diatom silica particles as new nano-hybrids: towards smart natural drug microcarriers. J Mater Chem B. 2013;1:6302.

46. Zhang L, Xia J, Zhao Q, Liu L, Zhang Z. Functional graphene oxide as a nanocarrier for controlled loading and targeted delivery of mixed anticancer drugs. Small. 2010;6(4):537-44.

47. Hoare TR, Kohane DS. Hydrogels in drug delivery: progress and challenges. Polymer. 2008;49(8):1993-2007.

48. Lotya M, Rakovich A, Donegan JF, Coleman JN. Measuring the lateral size of liquidexfoliated nanosheets with dynamic light scattering. Nanotechnol. 2013;24(26):265703.

49. Amaro-Gahete J, Benítez A, Otero R, Esquivel D, Jiménez-Sanchidrián C, Morales J, et al. A comparative study of particle size distribution of graphene nanosheets synthesized by an ultrasound-assisted method. Nanomaterials. 2019:9:152

50. Penkowa M, Keller C, Keller P, Jauffred S, Pedersen BK. Immunohistochemical detection of interleukin-6 in human skeletal muscle fibers following exercise. FASEB J. 2003;17(14):2166-8.

51. Wang H, Lafdil F, Kong X, Gao B. Signal transducer and activator of transcription 3 in liver diseases: a novel therapeutic target. Int J Biol Sci. 2011;7:536-50

\section{Publisher's Note}

Springer Nature remains neutral with regard to jurisdictional claims in published maps and institutional affiliations.

Ready to submit your research? Choose BMC and benefit from:

- fast, convenient online submission

- thorough peer review by experienced researchers in your field

- rapid publication on acceptance

- support for research data, including large and complex data types

- gold Open Access which fosters wider collaboration and increased citations

- maximum visibility for your research: over $100 \mathrm{M}$ website views per year

At $\mathrm{BMC}$, research is always in progress.

Learn more biomedcentral.com/submissions 